\title{
A review of mental health treatment dropout by ethnic minority youth
}

Authors: Anna M. de Haan ${ }^{\text {ab }}$, Albert E. Boon ${ }^{\text {abc }}$, Joop T.V.M. de Jong ${ }^{\text {def }} \&$ Robert R.J.M.

Vermeiren $^{\text {bg }}$

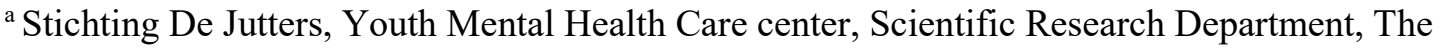
Hague, The Netherlands

${ }^{\mathrm{b}}$ Curium- Leiden University Medical Center, Department of Child and Adolescent Psychiatry, Leiden, The Netherlands.

${ }^{\mathrm{c}}$ De Fjord Lucertis, Center for Orthopsychiatry and Forensic Youth Psychiatry, Scientific

Research Department, Capelle aan den IJssel, The Netherlands.

${ }^{\mathrm{d}}$ University of Amsterdam, Amsterdam Institute of Social Science Research, Amsterdam, The Netherlands.

${ }^{\text {e }}$ Boston University School of Medicine, Department of Psychiatry, Boston, USA.

${ }^{\mathrm{f}}$ Rhodes University, Department of Psychology, Grahamstown, South Africa.

${ }^{g}$ VU University Medical Center, Department of Child and Adolescent Psychiatry, Amsterdam, The Netherlands.

Corresponding author:

Anna de Haan

a.m.de_haan@curium.nl

Word count text and references: 7255

Word count figure 1: 65

Word count table 1: 2908

Word count table 2: 312 


\title{
A review of mental health treatment dropout by ethnic minority youth
}

\author{
Abstract \\ Background A large proportion of the treatments in youth mental health care are prematurely \\ terminated by the individual. Treatment dropout can have severe consequences; thus, it is \\ relevant to explore the determinants. Since ethnic minority youth are treated less often for \\ mental disorders than other youth, it is important to analyse their risk for dropout and to \\ determine if there are ethnic-specific determinants. \\ Aims This review aimed to provide an overview of the findings from empirical studies on \\ child and adolescent therapy dropout by ethnic minorities and to determine if there were \\ ethnic-specific dropout determinants. \\ Methods An extensive literature search was performed to locate appropriate journal articles. \\ Identified articles were inspected for relevant references and these articles were then included. \\ A total of 27 studies were accepted for analysis. \\ Results The results showed that ethnic minority patients have a higher risk of treatment drop \\ out than ethnic majority patients and dropout rates are ethnically specific. Several differences \\ in dropout predictors among the ethnic groups were found. \\ Conclusions In spite of diverse results, review limitations, and the lack of several key \\ variables in the available research, some clinical recommendations are made. The review \\ indicates that to prevent dropout, therapists should pay attention to variables such as ethnic \\ background, therapist-patient ethnic match, and the quality of the therapeutic relationship.
}

\section{Key words}

Review; dropout; youth mental health care; ethnic minority; psychotherapy; children and adolescents. 


\section{Introduction}

An estimated 7\% of the children and adolescents in Western societies have impaired functioning to the degree that psychiatric treatment is recommended (Friedman, Katz-Levey, Manderschied, \& Sondheimer, 1996; Rutter \& Stevenson, 2008). This number appears to be similar across ethnic groups (Nikapota \& Rutter, 2008). However, in Western societies, only $2.5 \%$ of youth receives mental health care (De Haan, Boon, Vermeiren, \& De Jong, 2012; Meltzer, Gatward, Goodman, \& Ford, 2000; Zachrisson, Rödje, \& Mykletun, 2006). The percentage of ethnic minority youth receiving mental health care is even smaller. Only $1.5 \%$ of minority youth receive youth mental health care compared to $3.5 \%$ of ethnic majority youth (Copeland, 2006; De Haan, et al., 2012; Garland, et al., 2000; Kodjo \& Auinger, 2004). For the children and adolescents who do receive treatment, several studies have shown that an estimated 28\% - 75\% prematurely terminate psychotherapy (Baruch, Vrouva, \& Fearon, 2009; De Haan, Boon, De Jong, Hoeve, \& Vermeiren, 2013; Luk, et al., 2001; Midgley \& Navridi, 2006). Psychiatric treatment increases the likelihood that the psychiatric problems will be solved, thus when children drop out their disorders may persist or worsen later in life (Dulmus \& Wodarski, 1996; Lochman \& Salekin, 2003; Moffitt, Caspi, Harrington, \& Milne, 2002; Reis \& Brown, 1999; Woodward \& Fergusson, 2001). Because of the negative consequences of untreated disorders and dropouts from youth mental health services, it is important to identify dropout determinants to prevent this from occurring. Considering the fact that ethnic minority youth are treated less often for their mental health problems than ethnic majority youth, it is even more pressing to examine how their dropout rates compared to ethnic majority youth, and which dropout determinants are ethnic specific. Thus, we performed a literature review on what is known about therapy dropout by ethnic minority youth.

Contrary to adults, in most cases, youth do not seek treatment on their own. The motivation for entering and remaining in treatment largely depends on others, like parents, teachers or referral agencies. Parents frequently participate in their child's treatment and consequently, parent and family characteristics play a central role in the youth's continuation 
or termination of treatment (Armbruster \& Kazdin, 1994). From a recent meta-analysis of 48 studies on dropouts in youth mental health care, it became clear that study designs and dropout definitions have influenced the results of dropout predictors and percentages (De Haan, et al., 2013). Several of the dropout studies in this meta-analysis specifically focused on ethnic minority youth's treatment dropout, or they described the ethnic background of their respondent group. However, not all studies reported on the ethnic differences in dropout determinants, i.e., when describing the results, they did not take ethnic background into account (e.g., Gilbert et al., 1994, Lock et al., 2006, Jensen-Doss and Weisz, 2008, Johnson et al., 2009). The meta-analysis showed that both ethnic minority status and socioeconomic status (SES) were risk factors for dropping out in some, but not all, cases (De Haan, et al., 2013). Since ethnic background and socioeconomic status are often correlated (i.e., ethnic minorities often have a lower SES than ethnic majority youths) (CBS, 2009; Chen, Martin, \& Matthews, 2006; Saxena, Eliahoo, \& Majeed, 2002) and because both are seen as important interrelated variables causing ethnic differences in mental health care utilization (Garland, et al., 2005; Zimmerman, 2005), it is essential to focus on youths' SES and ethnic backgrounds.

The aim of the present literature review is to provide an overview of the findings from empirical studies on the premature termination of ethnic minority child and adolescent therapy and to expand the knowledge of psychotherapy dropout by specifically focusing on ethnic minorities in the studies included in the aforementioned meta-analysis (De Haan, et al., 2013). Information on dropout predictors (i.e., whether dropout determinants are ethnic specific) and dropout percentages (i.e., whether the dropout rates differ between ethnic minority youth and their ethnic majority peers) was investigated.

\section{Method}

\section{Literature search}

An extensive literature search was performed using PsycINFO, MEDLINE and Psychology and Behavioral Science Collection databases to locate journal articles on the subject of premature termination of therapy with children and adolescents. In addition, 
identified articles were inspected for additional relevant references, and these articles were also evaluated. The following key words were used in the search: premature termination, therapy, psychotherapy, treatment, ethnicity, ethnic background, minority background, dropout, and attrition. The option of 'remove duplicates' was chosen and the following limitations were added. Search results were limited to 'peer reviewed' articles and articles published between 1994 - 2013, 'age': childhood (birth - 12 yrs), all child (0-18 yrs), adolescence (13-18 yrs), school age (6-12 yrs), preschool age (2-5 yrs), child: 6-12 yrs, adolescent: 13-18 yrs.

In the initial search, articles that were ineligible based on the title or the first few words of the abstract were eliminated. Remaining articles were examined using the abstracts. Next, the first author reviewed the full-text versions of each article to make the final selection based on the inclusion and exclusion criteria. The second author independently verified whether the selected articles met the inclusion criteria. Figure 1 represents a flow diagram of the results of our literature research.

\section{Insert Figure 1 about here}

Inclusion criteria were studies: (a) in peer-reviewed articles in English, (b) in outpatient settings (not inpatient settings), (c) with a focus on psychiatric treatment in mental health services (e.g., not only medication management), (d) with subjects under 21 years of age, (e) with patients whose ethnic background was described and (f) with at least one minority ethnic group in the country where the study was performed. Exclusion criteria were studies: (a) on

preventing recidivism (i.e., sexual abusers, alcohol/drug abusers, forensic clients, etc.), (b) on medication management therapy (i.e., where dropout was defined as not adhering to prescribed medication), (c) that were theoretical or qualitative, (d) only focused on child retention or the number of visits without defining the status of termination (i.e., it was unclear whether someone was a dropout or a completer), (e) in which the subjects were mandated to 
treatment (e.g., forensic settings), and (f) that described patient ethnic backgrounds, but ethnic background was not a variable considered in the results or the discussion.

\section{Results}

Insert table 1 about here

A total of 27 studies were included in our review. See table 1 for details of the studies including demographics, location, SES, ethnicity, treatment, diagnosis, and dropout definition. Studies were divided into four groups by dropout percentages. The first group included five studies that reported on the dropout percentages by ethnic group. The second group included two studies that only included ethnic minority youth (i.e., Mexican-Americans in study 11 and various ethnic minorities in study 27) and analyzed whether the outcomes were different from the outcomes for ethnic majority youth in other studies. The third group consisted of 17 studies that did not report on the varying dropout percentages among ethnic groups, rather they analyzed whether a ethnic minority background was a dropout predictor, i.e., whether ethnic minority youth had a higher risk of dropping out than their ethnic majority peers. The last group included three studies that did not report on the dropout percentages of each ethnic group, or whether ethnic minority status was a risk factor. However, these studies did report on other ethnicity-related variables (e.g., an ethnic match between patient and therapist). With respect to dropout predictors, 19 of the 27 studies considered ethnic background (studies 1- 6, 9-11, 13-16, 19, 21, 23, 25-27). Three main dropout predictors were examined: SES, an ethnic match between the patient and the therapist, and the therapeutic relationship.

Insert table 2 about here

\section{Dropout percentages}


The results on dropout percentages are given in detail in Table 1 . Table 2 presents a summary of the main findings. In a study by Kazdin and Mazurick (1994) performed in the US, the dropout percentage for African-American children was $63.7 \%$, for other ethnic minority children $50 \%$, and for European-American children $37.7 \%$ (no statistical significance noted). In a later study by Kazdin et al. (1995), the dropout percentage for African-American children was 59.6\%, and for European-American children it was again lower with $41.7 \%(p<.01)$. A third study by Kazdin et al. (1997) only compared the minority group as a whole with non-minorities. Minorities had a dropout percentage of $52.4 \%$ and the non-minorities had a lower percentage of 32.9\% $(p<.001)$. Flicker et al. (2008) compared Hispanic-American adolescents with European-American adolescents and found higher dropout percentages for the Hispanic-American group (48.8\%) than for the EuropeanAmerican group (34.9\%) (no statistical significance noted). Lamb et al. (2002) also found higher non-attendance rates for Bangladeshi than for native English children in the UK ( $39.4 \%$ versus $26.9 \%[p<.05])$. According to nine other studies, ethnic minority background was a predictor for dropout or shorter treatment duration. Five of these nine studies included several ethnic groups (i.e., European-American, African-American, Hispanic-American, or Asian-American) although no further differentiation between specific ethnic minority groups was made (Armbruster \& Fallon, 1994; Bagner \& Graziano, 2013; Kazdin, Mazurick, \& Siegel, 1994; Kendall \& Sugarman, 1997; Schneider, Gerdes, Haack, \& Lawton, 2013). In three of these nine studies, several ethnic minority groups were compared with the EuropeanAmerican group, and a higher dropout risk for African-American youth was found, but not for the other minority groups (Gonzalez, Weersing, Warnick, Scahill, \& Woolston, 2011; Stein, Klein, Greenhouse, \& Kogan, 2012; Warnick, Gonzalez, Weersing, Scahill, \& Woolston, 2012). In one of these nine studies (Miller, Southam-Gerow, \& Allin Jr., 2008), only AfricanAmerican and European-American youth were included and here African-American ethnicity was also a dropout predictor.

In contrast, six studies stated that ethnic minority status was not a predictor for dropout (Dierker, Nargiso, Wiseman, \& Hoff, 2001; Garcia \& Weisz, 2002; Lau \& Weisz, 2003; Pina, 
Silverman, Weems, Kurtines, \& Goldman, 2003; Shelef, Diamond, Diamond, \& Liddle, 2005;

Stevens, Kelleher, Ward-Estes, \& Hayes, 2006). These studies all included several ethnic groups (i.e., European-American, African-American, Hispanic-American, and Asian-

American), but no further differentiation among ethnic groups was made. Analyses were only performed for the ethnic minority group as a whole versus the majority group.

Three studies stated that minority families were more likely to have completed therapy than majority families (Baruch, Gerber, \& Fearon, 1998; Halliday-Boykins, Schoenwald, \& Letourneau, 2005; McCabe, 2002). Unfortunately, Baruch et al. (1998) did not note which ethnic groups were included in the 'ethnic minority' category. Halliday-Boykins et al. (2005) found a lower dropout risk only for Asian-American versus European-American children. No differences were found for the other ethnic minority groups. In another study that specifically focused on Mexican-American children (with no comparison group), it was found that the minority patients had a rather low dropout rate (29\%) compared to rates found in other studies of ethnic majority youth (McCabe, 2002). Similarly, in a Dutch study on ethnic minority children (no native Dutch children included in sample) the dropout percentage was $35.7 \%$ (De Haan, Boon, De Jong, Geluk, \& Vermeiren, 2014). This dropout rate is similar to the dropout percentages found in most (European-American) majority groups seen in the aforementioned studies.

\section{Dropout predictors}

The results on dropout percentages are given in detail in Table 1. In Table 2, a summary of the main findings of dropout predictors is given. Eight studies found that a lower SES was not a predictor for dropout, independent of ethnic background (i.e., European-American, African-American, Hispanic-American, Asian-American, or Asians in Hong Kong) (Bagner \& Graziano, 2013; Flicker, et al., 2008; Garcia \& Weisz, 2002; Kazdin, et al., 1994; Lau \& Weisz, 2003; McCabe, 2002; Schneider, et al., 2013; Warnick, et al., 2012). Other studies did find an increasing dropout effect for patients with a lower SES. According to Armbruster and Fallon (1994), a lower SES was a dropout predictor, however, minority status (i.e., African 
American or Hispanic American) was not a dropout predictor after controlling for SES.

Kazdin and Mazurick (1994) stated that a lower SES was a dropout predictor in an early stage of treatment, but not for dropout in a later stage. Kazdin et al. (1995) found that

socioeconomic disadvantage was a dropout predictor in European-American families, but not in African-American families. In a later study by Kazdin et al. (1997), the authors found that socioeconomic disadvantage was a dropout predictor for all ethnic groups (i.e., EuropeanAmerican, African-American, Hispanic-American and Asian-American).

Three studies specifically focused on the differences in dropout predictors among ethnic groups. For instance, dropout predictors for European-American families were: having a younger mother, a single-parent family, high parental stress, parental psychopathology, child antisocial behavior, overall child dysfunction, lower child academic functioning, and adverse child rearing practices. For African-American families, only high parental stress, child antisocial behavior, lower child academic functioning, and adverse child rearing practices were found to predict dropout (Kazdin, et al., 1995). On the contrary, two studies did not find any difference in dropout predictors among ethnic groups (i.e., European-American, AfricanAmerican, and Hispanic-American) (Dierker, et al., 2001; Pina, et al., 2003).

Six studies focused on the effect of an ethnic match between patient and therapist on treatment dropout. European-American parents whose child was treated by an AfricanAmerican or Hispanic-American therapist had a higher risk for drop out than all other ethnic combinations of therapist and patient (Armbruster \& Fallon, 1994). According to HallidayBoykins et al. (2005) and Wintersteen et al. (2005), there was a high relationship between dropout and ethnic mismatch between parent and therapist for all ethnic backgrounds. In a study by Yeh et al. (1994), the effect of an ethnic match between therapist and child was only seen when the patient was an adolescent, i.e., an ethnic mismatch between therapist and adolescent patient predicted dropout for African-American, Hispanic-American and AsianAmerican adolescent patients, but not for European-Americans. For children, no effect of ethnic match with their therapist was found for treatment dropout. Similarly, McCabe (2002) 
and Flicker et al. (2008) found no effect of ethnic match between child and therapist for European-American, Hispanic-American or Mexican-American patients of any age.

With respect to a therapeutic alliance (define therapeutic alliance here), a reduction in both the parent-therapist and adolescent-therapist alliance from session one to session two was found to be associated with dropout for African-American families (Robbins, et al., 2006). For Hispanic families, an unbalanced alliance (i.e., parent-therapist alliance minus adolescent-therapist alliance) measured during the first session was found to relate to dropout, however, this was not a dropout predictor for European-American families (Flicker, et al., 2008). For ethnic minority children and adolescents in The Netherlands, it was found that a reduction in the self-rated quality of the therapeutic relationship during the course of treatment was related to dropout, which has also been found in other studies in native Dutch children (De Haan, Boon, De Jong, et al., 2014).

Warnick et al. (2012) compared dropout predictors using three dropout definitions. They concluded that African-American ethnicity was a dropout predictor when dropout was defined by 'clinician judgment' (i.e., youths were classified as dropouts based on the clinician coded reason for discharge) or by 'missing the last appointment', but not when dropout was defined by 'dose' (i.e., youths were classified as dropouts when they attended less than 12 sessions within four months). Hispanic ethnicity, on the other hand, was a predictor for dropout if it was defined by 'missing the last appointment' or by 'dose'. Similarly, Schneider et al. (2013) found that ethnic minority status only was a predictor for dropout prior to treatment, but not during treatment.

\section{Discussion}

The aim of this literature review was to provide an overview of the findings (i.e., dropout percentages and dropout predictors) from empirical studies on premature termination by ethnic minorities in child and adolescent therapy. Specifically, information on dropout predictors (i.e., whether dropout determinants are ethnic specific) and dropout percentages (i.e., whether dropout rates differ among ethnic groups) was gathered. It became clear that 
few studies focus on ethnic background and mental health treatment dropout. In addition, the studies that did focus on this subject showed conflicting results and dropout predictors were only evaluated in a small number of publications.

There are some methodological issues that might explain the inconsistencies in the findings. For instance, some of the studies had a small number of respondents in relation to the high number of predictors analyzed. When multiple predictors are included, it is recommended that that there should be at least 10 respondents per predictor. This rule was violated in some of the studies. Also, the results might have been influenced by the definitions chosen for ethnicity, SES and dropout, which varied widely across studies. In addition, it is possible that important variables associated with race that influenced the results were not investigated, e.g., often ethnic minorities have a lower SES than ethnic majority children, or children with a certain ethnic background might be treated for a certain disorder more often than others (De Haan, Boon, Vermeiren, \& De Jong, 2014). Unfortunately, as presented in Table 1, the studies did not provide information about the SES or specific disorder distribution per ethnic group. Therefore, we do not know whether the increased or decreased risk of dropout for certain ethnic groups was mediated by variables such as diagnosis or SES. Practical obstacles that may be associated with a both lower SES and ethnic minority status (e.g., long distance to institution, unable to pay for the bus, or no mental health insurance) can result in a higher risk for drop out. Indeed, in one study (Armbruster \& Fallon, 1994) it appeared that the increasing effect of minority status on dropout was not present when SES was taken into account. This indicates that a lower SES and not ethnic minority status was the most important dropout predictor. Unfortunately, these factors were only compared in one study and therefore no firm conclusions can be given.

An important aspect to consider is that almost all studies were conducted in the US. Only two studies were conducted in the UK, and one was conducted in The Netherlands. To increase homogeneity of the ethnic minority groups we could have focused on the US situation. The intention was however to review all eligible papers worldwide to be as 
comprehensive as possible. It is an interesting finding that so little papers outside the US on this topic were eligible. It is therefore unclear whether the results are generalizable for countries outside the US. For instance, there are clear differences in mental health care availability and mental health insurance among countries. In most western European countries, the utilization of health care services is largely independent from financial constraints, and in general all children and adolescents are covered by public or private health insurance (Zwaanswijk, Van der Ende, Verhaak, Bensing, \& Verhulst, 2005). The results of US studies may thus not be directly applicable to countries outside the US. This is an important issue to consider, because there have been few dropout studies conducted outside the US until recently. We hope that the results of present review will motivate researchers from outside the US to conduct dropout studies as well.

Another important issue is the definition of minority background, which is defined by race in most studies. This might indirectly suggest that racialized identities are imposed on the youth which influences both the way that therapy is delivered by clinicians as the way that therapy is received by the patients. For instance, several studies found that clinicians were susceptible to information-gathering biases that influenced the diagnostic process, such as seeking information to confirm the diagnosis while ignoring conflicting information, and making decisions based on assumptions about ethnicity (Garb, 2005; Torres, Zayas, Cabassa, \& Perez, 2007; Zayas, Cabassa, Perez, \& Howard, 2005). As a consequence of potential misdiagnoses, ethnic minority youth might not be receiving the right treatment for their disorder, thus affecting the course and the outcome of treatment and a higher dropout rate might be one of the consequences (Jensen-Doss \& Weisz, 2008). It should be noted that the youth population that participated in the included studies was heterogeneous with respect to diagnosis, which might have influenced the results. Indeed, some of the studies specifically focused on anorexia nervosa, conduct disorders, or anxiety disorders, while other studies focused on a wide range of problems without specific diagnoses. The type of treatment differed per study as well, since some studies focused on family therapy, social skills training, 
or exposure-based treatment, while others did not specify the type of treatment the youth was receiving. The variations in study population or in treatment type could also have influenced the differences or lack of differences found in our review.

How dropout was defined might also have influenced the results. Some ethnic groups might terminate treatment more often at a certain stage of treatment (e.g., prior to treatment, after just 1-2 sessions, or after one year) and thus finding an effect of ethnic minority status on treatment dropout may depend on the definition. Another important issue to consider is that in general ethnic minorities are less likely to receive mental health services than the majority population (Boon, De Haan, De Boer, \& Klasen, 2014; De Haan, et al., 2012; Goodman, Patel, \& Leon, 2008; Ivert, Merlo, Svensson, \& Levander, 2013). This indicates that youth who enter mental health treatment are not representative of the entire local population. This might have influenced the results found in the reviewed studies; therefore, it is difficult to make comparisons across ethnicities.

A limitation of this review's methodology is that only peer-reviewed published studies in the English language were included. There might be significantly more information available that we could not include in our review. Studies published in languages other than English could provide information on therapy with youth in countries outside the US and England. Second, we were not able to conduct a meta-analysis. A meta-analysis would have given more structured information on effect sizes per ethnic group for the dropout predictors and dropout percentages. However, only five of the 27 included studies (study 2, 5, 6, 12, 21) reported on percentages per ethnic group, and only six studies reported on dropout predictors per ethnic group (study 4, 5, 13, 16, 19, 21). Most dropout predictors were only described in one or two studies. Therefore, effect sizes per dropout predictor could only have been calculated based on the information from one or two studies. This would have resulted in unrealistic effect sizes, so no meta-analysis was conducted. A third limitation is that we did not report on therapy settings other than outpatient, because this was beyond the scope of this review. Therefore, our results cannot be generalized to other settings such as inpatient therapy, forensic treatment, alcohol or drug treatment, internet therapy, etc. 
An important limitation of the included studies is that they often only focused on pretreatment child and family variables that were present prior to treatment and could not be changed during treatment. In an early review on treatment dropout in child and adolescent psychiatry (Armbruster \& Kazdin, 1994), the authors stated that mere identification of the static variables for treatment dropout without a conceptualization of the underlying processes of premature termination is unlikely to improve our understanding. The first theoretical model introduced for these underlying processes was the barriers-to-treatment-participation model (Kazdin, Holland, \& Crowley, 1997; Kazdin, Holland, Crowley, \& Breton, 1997). This model proposed that families experience multiple barriers associated with participating in mental health treatment and these barriers increase the risk for dropping out. Barriers include stressors and obstacles that compete with treatment participation (such as conflict with a significant other about coming to treatment), treatment demands and issues (too costly or too lengthy), perceived relevance of treatment (treatment is of little relevance to the child's problems), and the relationship with the therapist (little perceived support from the therapist). The absence of barriers might serve as a protective factor (i.e., for families with a high risk for dropping out, the perception of few barriers might attenuate the risk), while the presence of barriers could serve as a mediator to explain how other (static) predictors operate to produce dropout (Kazdin, Holland, Crowley, et al., 1997). Thus, a potential barrier such as negative experience in the therapeutic relationship might mediate the process of how static variables such as ethnic background and socioeconomic status relate to dropout. It is of utmost importance that both static pre-treatment variables and barriers to potential participation in treatment are taken into account in future dropout studies.

Several important issues are lacking in published research to date. For instance, little is known about the differences in the quality of the therapeutic relationship between ethnically matched therapist-patient dyads and non-matched dyads. Combining these two issues could teach us more about the effect of ethnic matching on the quality of the therapeutic relationship and its effect on treatment dropout. We recommend that these elements be combined in future dropout studies. Information about the type of therapy offered was often missing in the 
reviewed studies. Thus, we cannot know whether specific elements of the therapy influenced the results. Therefore, we recommend that all future studies on treatment dropout should report the type of therapy. We also do not know why the study subjects dropped out of treatment in the included studies. It is possible that some patients prematurely terminated therapy because they (or their parents) believe they have benefitted enough (while the therapist disagrees) and whether these patients should be seen as dropouts in the negative sense. Ideally, all youth who prematurely terminate treatment are asked about their reasons for dropping out.

The authors of the abovementioned theory developed a questionnaire about the reasons for (prematurely) terminating therapy. This questionnaire, the "Barriers to Treatment Participation Scale (BTPS)", is to be completed at the point of therapy termination (Kazdin, Holland, Crowley, et al., 1997). An apparent problem with dropouts is they are often hard to reach and thus often will not complete questionnaires administered after termination. Some salient perspectives on this subject can be found in the work of a recent national UK project "Improving Access to Psychological Therapy", also known as IAPT (Clark, 2011; Clark, et al., 2009). Here the therapists are expected to collect patient feedback (by questionnaire) after every session. In this way, it is assured that a measure of the experienced severity of a patient's disorder at the last clinical contact is noted for all clients, including those individuals who drop out or complete treatment earlier than anticipated. This is an advantage over the usual method of administering questionnaires at the start and end of therapy which usually produces low response rates from individuals who drop out or complete treatment earlier than anticipated. The analyses in one reviewed study (i.e., questionnaires completed after every session were compared with the less frequently administered questionnaires) strongly suggest that patients who fail to provide post-treatment data in conventional outcome-monitoring systems (i.e., the dropouts or other early terminators) are likely to have done less well clinically than the patients who provide post-treatment data (Clark, et al., 2009). Researchers can learn from the results of the IAPT project that it is useful to collect data over several 
sessions of therapy to assure that data from dropouts and other early terminators are also available.

\section{Conclusions}

In spite of the limitations mentioned above, we provide some conclusions and recommendations for clinical practice. Our review indicates that therapists be aware when they begin therapy with children and adolescents with certain characteristics. The most obvious finding was that an African-American background can be a risk factor for therapy dropout, and therefore, it is advised that therapists are aware of this increased dropout risk when starting treatment with African-American children and adolescents. Dropout among African-American patients may take place at the earliest stages of treatment, so extra clinical attention should be focused on this population at triage, or even before, if possible, at the moment of referral. This increased dropout risk might be due to perceived racism, a preference for informal therapies outside the medical system, religious coping, or traditional explanations of illness and symptoms that do not match with the therapist's explanations. For children and adolescents of other ethnic minority backgrounds, the risk may not be higher than that of ethnic majority patients. Next, a lack of ethnic matching among adolescent patients and their therapists can be a dropout predictor, although a lower SES is probably not. An ethnic match between the therapist and the adolescent patient may increase the chance that the patient will complete therapy. In order to prevent treatment dropout, mental health institutions might try to ethnically match their patients and clinicians when possible. It is also important for clinicians to be aware of the therapeutic alliance since a negative or decreasing quality of the therapeutic alliance can increase the dropout risk for patients of various ethnic backgrounds.

It is recommended that if there is a drop in the rated quality of the therapeutic relationship, the therapist should communicate this to the patient (i.e., give feedback) and it might even be considered to arrange switching therapists (De Haan, Boon, De Jong, et al., 2014). It is probable that giving feedback to the patient about the course of the therapeutic 
relationship will lead to an improvement in this relationship, and this could lead to a decrease in dropout and an increased chance of therapy completion. Clinicians should pay attention to several factors in addition to a child or adolescent's ethnic background, such as the ethnic match and the therapeutic relationship. Patients with high parental stress, child antisocial behavior, lower child academic functioning, and adverse child-rearing practices might have a higher risk for dropping out of mental health treatment.

It is unclear whether these implications for clinical practice can be generalized to countries outside the US, England, Hong Kong or The Netherlands. They might account for clinical practice elsewhere as well, but we do not have enough information on therapy with ethnic minorities in countries outside of these four countries. Therefore, we recommend that more treatment dropout studies (and English publication of these studies) should be done in countries outside of the US and with ethnic groups not found in the US. In future studies, it is recommended that both static pre-treatment variables and potential barriers to treatment participation are analyzed, the definitions of ethnicity and socioeconomic status are similar per country, and the definition of dropout is similar across studies. Also, results on dropout percentages and dropout predictors should be reported per ethnic group. It would be best to conduct longitudinal follow-up studies for the problems highlighted in this review.

Unfortunately, these types of studies are also the most difficult and expensive. However, conducting studies with these considerations will make it possible to compare results and give meaningful clinical implications. 


\section{References}

Armbruster, P., \& Fallon, T. (1994). Clinical, sociodemographic, and systems risk factors for attrition in a children's mental health clinic. American Journal of Orthopsychiatry, 64(4), 577-585.

Armbruster, P., \& Kazdin, A. E. (1994). Attrition in child therapy. In T. H. Ollendick \& T. J. Prinz (Eds.), Advances in clinical child psychology (Vol. 16, pp. 81-108). New York: Plenum.

Bagner, D. M., \& Graziano, P. A. (2013). Barriers to success in parent training for young children with developmental delay: The role of cumulative risk. Behavior Modification, 37(3), 356-377.

Baruch, G., Gerber, A., \& Fearon, P. (1998). Adolescents who drop out of psychotherapy at a community-based psychotherapy centre: A preliminary investigation of the characteristics of early drop-outs, late drop-outs and those who continue treatment. British Journal of Medical Psychology, 71, 233-245.

Baruch, G., Vrouva, I., \& Fearon, P. (2009). A follow-up study of characteristics of young people that dropout and continue psychotherapy: Service implications for a clinic in the community. Child and Adolescent Mental Health, 14(2), 69-75.

Boon, A. E., De Haan, A. M., De Boer, S. S. B., \& Klasen, H. (2014). Differences in ethnic background between regular and forensic youth mental health care patients. International Journal of Clinical Psychiatry and Mental Health, 2, 1-9.

CBS. (2009). Centraal Bureau voor de Statistiek. Statline. Voorburg: CBS.

Chen, E., Martin, A. D., \& Matthews, K. A. (2006). Understanding health disparities: The role of race and socioeconomic status in children's health. American Journal of Public Health, 96(4), 702-708.

Clark, D. M. (2011). Implementing NICE guidelines for the psychological treatment of depression and anxiety disorders: The IAPT experience. International Review of Psychiatry, 23(4), 318-327.

Clark, D. M., Layard, R., Smithies, R., Richards, D. A., Suckling, R., \& Wright, B. (2009). Improving access to psychological therapy: Initial evaluation of two UK demonstration sites. Behaviour research and therapy, 47(11), 910-910.

Copeland, V. C. (2006). Disparities in mental health service utilization among low-income African American adolescents: Closing the gap by enhancing practitioner's competence. Child \& Adolescent Social Work Journal, 23(4), 407-431.

De Haan, A. M., Boon, A. E., De Jong, J. T. V. M., Geluk, C. A., \& Vermeiren, R. R. J. M. (2014). Therapeutic relationship and dropout in youth mental health care with ethnic minority children and adolescents. Clinical Psychologist, 18(1): 1-9.

De Haan, A. M., Boon, A. E., De Jong, J. T. V. M., Hoeve, M., \& Vermeiren, R. R. J. M. (2013). A meta-analytic review on treatment dropout in child and adolescent outpatient mental health care. Clinical Psychology Review, 33(5), 698-711.

De Haan, A. M., Boon, A. E., Vermeiren, R. R. J. M., \& De Jong, J. T. V. M. (2012). Ethnic differences in utilization of Youth Mental Health Care. Ethnicity and Health, 17(1-2), $105-110$.

De Haan, A. M., Boon, A. E., Vermeiren, R. R. J. M., \& De Jong, J. T. V. M. (2014). Ethnic differences in DSM-classifications in Youth Mental Health Care practice. International Journal of Culture and Mental Health, 7 (3): 284-296.

Dierker, L., Nargiso, J., Wiseman, R., \& Hoff, D. (2001). Factors predicting attrition within a community initiated system of care. Journal of Child and Family Studies, 10(3), 367383.

Flicker, S. M., Turner, C. W., Waldron, H. B., Brody, J. L., \& Ozechowski, T. J. (2008). Ethnic bakcground, therapeutic alliance, and treatment retention in functional family therapy with adolescents who abuse substances. Journal of Family Psychology, 22(1), 167-170.

Friedman, R. M., Katz-Levey, J. W., Manderschied, R. W., \& Sondheimer, D. L. (1996). Prevalence of serious emotional disturbance in children and adolescents. In R. W. 
Manderscheid \& M. A. Sonnenschein (Eds.), Mental health, United States (pp. 7188). Rockville, MD: Center for Mental Health Services.

Garb, H. N. (2005). Clinical judgment and decision making. Annual Review of Clinical Psychology, 1(1), 67-89.

Garcia, J. A., \& Weisz, J. R. (2002). When youth mental health care stops: Therapeutic relationship problems and other reasons for ending youth outpatient treatment. Journal of Consulting and Clinical Psychology, 70(2), 439-443.

Garland, A. F., Hough, R. L., Landsverk, J. A., McCabe, K. M., Yeh, M., Ganger, W. C., et al. (2000). Racial and ethnic variations in mental health care utilization among children in foster care. Children's Services: Social Policy, Research, \& Practice, 3(3), 133-146.

Garland, A. F., Lau, A. S., Yeh, M., McCabe, K. M., Hough, R. L., \& Landsverk, J. A. (2005). Racial and ethnic differences in utilization of mental health services among high-risk youths. American Journal of Psychiatry, 162(7), 1336.

Gonzalez, A., Weersing, V. R., Warnick, E. M., Scahill, L. D., \& Woolston, J. L. (2011). Predictors of treatment attrition among an outpatinet clinic sampe of youths with clinically significant anxiety. Administration and Policy in Mental Health and Mental Health Services Research, 38(5), 356-367.

Goodman, A., Patel, V., \& Leon, D. A. (2008). Child mental health differences amongst ethnic groups in Britain: a systematic review. BMC Public Health, 8(1), 258- 268.

Halliday-Boykins, C. A., Schoenwald, S. K., \& Letourneau, E. J. (2005). Caregiver-therapist ethnic similarity predicts youth outcomes from an empirically based treatment. Journal of Consulting and Clinical Psychology, 73(5), 808-818.

Ivert, A. K., Merlo, J., Svensson, R., \& Levander, M. T. (2013). How are immigrant background and gender associated with the utilization of psychiatric care among adolescents? Social Psychiatry and Psychiatric Epidemiology, 48, 693-699.

Jensen-Doss, A., \& Weisz, J. R. (2008). Diagnostic agreement predicts treatment process and outcomes in youth mental health clinics. Journal of Consulting and Clinical Psychology, 76(5), 711-722.

Kazdin, A. E., Holland, L., \& Crowley, M. (1997). Family experience of barriers to treatment and premature termination from child therapy. Journal of Consulting and Clinical Psychology, 65(3), 453-463.

Kazdin, A. E., Holland, L., Crowley, M., \& Breton, S. (1997). Barriers to treatment participation scale: Evaluation and validation in the context of child outpatient treatment. Journal of Child Psychology and Psychiatry, 38(8), 1051-1062.

Kazdin, A. E., \& Mazurick, J. L. (1994). Dropping out of child psychotherapy: Distinguishing early and late dropouts over the course of treatment. Journal of Consulting and Clinical Psychology, 62(5), 1069-1074.

Kazdin, A. E., Mazurick, J. L., \& Siegel, T. C. (1994). Treatment outcome among children with externalizing disorder who terminate prematurely versus those who complete psychotherapy. Journal of the American Academy of Child and Adolescent Psychiatry, 33, 549-457.

Kazdin, A. E., Stolar, M. J., \& Marciano, P. L. (1995). Risk Factors for Dropping Out of Treatment among White and Black Families. Journal of Family Psychology, 9(4), 402-417.

Kendall, P. C., \& Sugarman, A. (1997). Attrition in the treatment of childhood anxiety disorders. Journal of Consulting and Clinical Psychology, 65(5), 383-388.

Kodjo, C. M., \& Auinger, P. (2004). Predictors for Emotionally Distressed Adolescents to Receive Mental Health Care. Journal of Adolescent Health, 35(5), 368-373.

Lamb, G., Anfield, A., \& Sheeran, A. (2002). Access to a child mental health service. A comparison of Bangladeshi and non-Bangladeshi families. Psychiatric Bulletin, 26, $15-18$.

Lau, A. S., \& Weisz, J. R. (2003). Reported maltreatment among clinic-referred children: implications for presenting problems, treatment attrition, and long-term outcomes. 
Journal of American Academy for Child and Adolescent Psychiatry, 42(11), 13271334.

Luk, E. S. L., Staiger, P. K., Mathai, J., Wong, L., Birleson, P., \& Adler, R. (2001). Children with Persistent Conduct Problems who Dropout of Treatment. European Child and Adolescent Psychiatry, 10, 28-36.

McCabe, K. M. (2002). Factors that predict premature termination among Mexican-American children in outpatient therapy. Journal of Child and Family Studies, 11(3), 347-359.

Meltzer, H., Gatward, R., Goodman, R., \& Ford, T. (2000). The mental health of children and adolescents in Great Britain. Londen: Stationery Office.

Midgley, N., \& Navridi, E. (2006). An exploratory study of premature termination in child analysis. Journal of Infant, Child, and Adolescent Psychotherapy, 5(4), 437-458.

Miller, L. M., Southam-Gerow, M. A., \& Allin Jr., R. B. (2008). Who stays in treatment? Child and family predictors of youth client retention in a public mental health agency. Child Youth Care Forum, 37(4), 153-170.

Nikapota, A., \& Rutter, M. (2008). Sociocultural/Ethnic groups and psychopathology. . In M. Rutter, D. Bishop, D. Pine, S. Scott, J. Stevenson, E. Taylor \& A. Thapar (Eds.), Rutters's child and adolescent psychiatry. Fifth edition. (pp. 199-211). Oxford: Blackwell Publising.

Pina, A. A., Silverman, W. K., Weems, C. F., Kurtines, W. M., \& Goldman, M. L. (2003). A comparison of completers and non-completers of exposure-based cognitive and behavioral treatment for phobic and anxiety disorders in youth. Journal of Consulting and Clinical Psychology, 71(4), 701-705.

Robbins, M. S., Liddle, H. A., Turner, C. W., Dakof, G. A., Alexander, J. F., \& Kogan, S. M. (2006). Adolescent and parent therapeutic alliance as predictors of dropout in multidimensional family therapy. Journal of Family Psychology, 20(1), 108-116.

Rutter, M., \& Stevenson, J. (2008). Using epidemiology to plan services: A conceptual approach. In M. Rutter, D. Bishop, D. Pine, S. Scott, J. Stevenson, E. Taylor \& A. Thapar (Eds.), Rutters's child and adolescent psychiatry. Fifth edition. Oxford: Blackwell Publishing.

Saxena, S., Eliahoo, J., \& Majeed, A. (2002). Socioeconomic and ethnic group differences in self reported health status and use of health servcies by children and young people in England: Cross sectional study. British Medical Journal, 325(7363), 520-526.

Schneider, B. W., Gerdes, A. C., Haack, L. M., \& Lawton, K. E. (2013). Predicting treatment dropout in parent training interventions for families of school-aged children with ADHD. Child \& Family Behavior Therapy, 35(2), 144-169.

Shelef, K., Diamond, G. M., Diamond, G. S., \& Liddle, H. A. (2005). Adolescent and parent alliance and treatment outcome in multidimensional family therapy. Journal of Consulting and Clinical Psychology, 73(4), 689-698.

Stein, B. D., Klein, G. R., Greenhouse, J. B., \& Kogan, J. N. (2012). Treatment of attentiondeficit hyperactivity disorder: patterns of evolving care during the first treatment episode. Psychiatric Services, 63(2), 122-129.

Stevens, J., Kelleher, K. J., Ward-Estes, B. S., \& Hayes, J. (2006). Perceived barriers to treatment and psychotherapy attendance in child community mental health centers Community Mental Health Journal, 42(5), 449-458.

Torres, L. R., Zayas, L. H., Cabassa, L. J., \& Perez, M. C. (2007). Diagnosing co-occurring substance-related disorders: Agreement between SCID, Hispanic clinicians, and nonHispanic clinicians. Journal of Clinical Psychiatry, 68(11), 1655-1662.

Warnick, E. M., Gonzalez, A., Weersing, V. R., Scahill, L. D., \& Woolston, J. L. (2012). Defining dropout from youth psychotherapy: how definitions shape the prevalence and predictors of attrition. Child and Adolescent Mental Health, 17(2), 76-85.

Wintersteen, M. B., Mensinger, J. L., \& Diamond, G. M. (2005). Do gender and racial differences betwen patient and therapist affect therapeutic alliance and treatment retention in adolescents? Professional Psychology Research and Practice, 36(4), 400408. 
Yeh, M., Eastman, K., \& Cheung, M. K. (1994). Children and adolescents in community health care centers: Does the ethnicity or the language of the therapist matter?

Journal of Community Psychology, 22, 153-163.

Zachrisson, H., Rödje, K., \& Mykletun, A. (2006). Utilization of health services in relation to mental health problems in adolescents: a population based survey. BMC Public Health, 6(1), 34.

Zayas, L. H., Cabassa, L. J., Perez, M. C., \& Howard, M. O. (2005). Clinician-patient ethnicity in psychiatric diagnosis: A pilot study with Hispanics. Journal of Ethnic and Cultural Diversity in Social Work: Innovation in Theory, Research and Practice, 14(1-2), 93-109.

Zimmerman, F. J. (2005). Social and economic dterminants of disparities in professional helpseeking for child menal health problems: Evidence from a national sample. Health Services Research, 40(5), 1514-1533.

Zwaanswijk, M., Van der Ende, J., Verhaak, P. F. M., Bensing, J. M., \& Verhulst, F. C. (2005). Help-seeking for child psychopathology: pathways to informal and professional services in the Netherlands. Journal of the American Academy of Child and Adolescent Psychiatry, 44(12), 1292. 
Table 1: Description of the included studies

\begin{tabular}{|c|c|c|c|c|c|c|c|}
\hline Study & $\begin{array}{l}\mathrm{N} \text { (age) }+ \\
\text { Country of } \\
\text { study }\end{array}$ & $\begin{array}{l}\text { Definition of SES + } \\
\text { distribution }\end{array}$ & $\begin{array}{l}\text { Definition of minority } \\
\text { status + Sample size } \\
\text { per ethnic group }\end{array}$ & $\begin{array}{l}\text { Treatment type }+ \\
\text { Type of mental } \\
\text { health problems }\end{array}$ & Definition of drop-out & Dropout predictors & Dropout \% \\
\hline \multicolumn{8}{|c|}{ Group 1: studies reporting on different dropout percentages between ethnic groups } \\
\hline $\begin{array}{l}\text { 2. Kazdin \& } \\
\text { Mazurick } \\
(1994)\end{array}$ & $\begin{array}{l}257 \\
(4-13) \\
\text { United } \\
\text { States }\end{array}$ & $\begin{array}{l}\text { Hollingshead } \\
\text { socioeconomic class } \\
\text { (from low to high) } \\
30.7 \% \text { class } 5,32.5 \% \\
\text { class } 4 \text {, } \\
24.2 \% \text { class } 3,7.8 \% \\
\text { class } 2,4.8 \% \text { class } 1\end{array}$ & $\begin{array}{l}\text { Definition by race } \\
40.1 \% \text { minority } \\
(35.4 \% \text { Black, } 3.5 \% \\
\text { Hispanic, } 0.8 \% \text { Asian, } \\
0.4 \% \text { mixed })\end{array}$ & $\begin{array}{l}\text { Cognitive problem- } \\
\text { solving skills training } \\
\text { and Parent } \\
\text { management training } \\
\text { Oppositional, } \\
\text { aggressive, antisocial } \\
\text { behavior disorders }\end{array}$ & $\begin{array}{l}\text { Premature termination on } \\
\text { the basis of a unilateral } \\
\text { decision by parent or } \\
\text { family, while inadvisable } \\
\text { and against advice of } \\
\text { clinical team. Early d.o.: } \\
\text { completed } 6 \text { or fewer } \\
\text { treatment weeks ( } 1 \\
\text { session per week), late } \\
\text { d.o.: termination form } 7 \text { to } \\
14 \text { weeks of treatment. }\end{array}$ & $\begin{array}{l}\text { Predictors early d.o.: more severe child } \\
\text { impairment in relation to conduct disorder and } \\
\text { delinquency, academic dysfunction, and social } \\
\text { behavior, younger single parents, minority } \\
\text { background, lower socioeconomic status, } \\
\text { greater family stress and greater life events. } \\
\text { Predictors late d.o.: younger mother, child } \\
\text { antisocial history, lower IQ, nonbiological head } \\
\text { of household, poor adaptive functioning at } \\
\text { school. }\end{array}$ & $\begin{array}{l}\text { Early d.o. }= \\
29,2 \% \\
\text { Late d.o. }= \\
18,3 \% \\
\text { d.o. White = } \\
37.7 \% \\
\text { d.o. Black = } \\
63.7 \% \\
\text { d.o. other = } \\
50 \%\end{array}$ \\
\hline $\begin{array}{l}\text { 5. Kazdin et } \\
\text { al. (1995) }\end{array}$ & $\begin{array}{l}279 \\
(3-13) \\
\text { United } \\
\text { States }\end{array}$ & $\begin{array}{l}\text { Hollingshead } \\
\text { socioeconomic class } \\
27.9 \% \text { class } 5,33.3 \% \\
\text { class } 4 \text {, } \\
25.2 \% \text { class } 3,8.1 \% \\
\text { class } 2,5.4 \% \text { class } 1\end{array}$ & $\begin{array}{l}\text { Self-identification } \\
64.5 \% \text { White, } 35.5 \% \\
\text { Black }\end{array}$ & $\begin{array}{l}\text { Cognitive problem- } \\
\text { solving skills } \\
\text { training, Parent } \\
\text { management training } \\
\text { Oppositional, } \\
\text { aggressive, antisocial } \\
\text { behavior disorders }\end{array}$ & $\begin{array}{l}\text { Premature termination } \\
\text { based on the unilateral } \\
\text { decision by parent or } \\
\text { family, while inadvisable } \\
\text { and against advice of } \\
\text { clinical team. }\end{array}$ & $\begin{array}{l}\text { Predictors White children: socioeconomic } \\
\text { disadvantage, younger mother, single-parent } \\
\text { family, high parental stress, parental } \\
\text { psychopathology, child antisocial behavior, } \\
\text { overall child dysfunction, lower child academic } \\
\text { functioning, adverse child rearing practices. } \\
\text { Predictors Black children: high parental stress, } \\
\text { child antisocial behavior, lower child academic } \\
\text { functioning, adverse child rearing practices. }\end{array}$ & $\begin{array}{l}\text { d.o. } \text { Black = } \\
59,6 \% \\
\text { d.o. White }= \\
41,7 \%\end{array}$ \\
\hline $\begin{array}{l}\text { 6. Kazdin et } \\
\text { al. }(1997)\end{array}$ & $\begin{array}{l}242 \\
(3-14) \\
\text { United } \\
\text { States }\end{array}$ & $\begin{array}{l}\text { Hollingshead } \\
\text { socioeconomic class } \\
25.1 \text { class } 5,31.5 \% \\
\text { class } 4 \text {, } \\
23.4 \% \text { class } 3,11.5 \% \\
\text { class } 2,8.5 \% \text { class } 1\end{array}$ & $\begin{array}{l}\text { Self-identification } \\
63.6 \% \text { White, } 26.9 \% \\
\text { African-American, } \\
6.6 \% \text { Hispanic- } \\
\text { American, } 2.9 \% \text { other }\end{array}$ & $\begin{array}{l}\text { Cognitive problem- } \\
\text { solving skills } \\
\text { training, Parent } \\
\text { management training } \\
\text { Oppositional, } \\
\text { aggressive, antisocial } \\
\text { behavior disorders }\end{array}$ & $\begin{array}{l}\text { Premature termination } \\
\text { based on the unilateral } \\
\text { decision by parent or } \\
\text { family, while inadvisable } \\
\text { and against advice of } \\
\text { clinical team. It occurred } \\
\text { when parent noted } \\
\text { explicitly that they did not } \\
\text { wish to continue or when } \\
\text { they did not come for at }\end{array}$ & $\begin{array}{l}\text { Predictors: socioeconomic disadvantage, ethnic } \\
\text { minority background, single parent, younger } \\
\text { parent, harsh child-rearing practices, parent } \\
\text { history of antisocial behavior, child history of } \\
\text { greater antisocial symptoms, higher levels of } \\
\text { perceived barriers to treatment (especially } \\
\text { among high risk cases), lower perceived } \\
\text { relevance of treatment. }\end{array}$ & $\begin{array}{l}\text { d.o. }=39,7 \% \\
\text { d.o. White }= \\
32.9 \% \\
\text { d.o. ethnic } \\
\text { minority = } \\
52.4 \%\end{array}$ \\
\hline
\end{tabular}



12. Lamb et 444
al. (2002)
(6-12)
No information
England
$28.8 \%$ Bangladeshi,
$71.2 \%$ native English

treatment type

All types of mental

health disorders

$\begin{array}{llll}\text { 21. Flicker } & 86 & \text { Hollingshead } & \text { Self-identification } \\ \text { et al. (2008) } & (13-19) & \text { socioeconomic status } & \text { 50\% Caucasian, 50\% } \\ & \begin{array}{l}\text { United } \\ \text { States }\end{array} & \begin{array}{l}\text { No information on } \\ \text { distribution }\end{array} & \text { Hispanic } \\ & & & \end{array}$

Functional family

therapy

Substance abuse or

dependence disorders least 3 consecutive weeks.

Non-attenders

early d.o.: attended only

once

late d.o.: attended more

than once but treatment

unilaterally terminated by

family

Not completing all

therapy sessions for which

they were scheduled
Early and late d.o. both groups $=36,4 \%$

Predictors non-attendance: referral by health

visitors (as opposed to referral by the hospital)

Predictors Hispanic families: unbalanced

alliances measured during the first session (i.e.

parent-therapist alliance minus adolescent-

therapist alliance)

No predictors Caucasian families: unbalanced

alliances

No predictors in general: socioeconomic status,

ethnic match with therapist

\begin{tabular}{|c|c|c|c|c|c|c|c|}
\hline $\begin{array}{l}\text { 11. McCabe } \\
\text { (2002) }\end{array}$ & $\begin{array}{l}50 \\
(6-12) \\
\text { United } \\
\text { States }\end{array}$ & $\begin{array}{l}\text { Parent income and } \\
\text { parent education } \\
\text { The sample was } \\
\text { largely low income } \\
\text { and there was an } \\
\text { average of less than } \\
\text { high school education }\end{array}$ & $\begin{array}{l}\text { Self-identification } \\
\text { All Mexican- } \\
\text { American }\end{array}$ & $\begin{array}{l}\text { No information on } \\
\text { treatment type } \\
\text { All types of mental } \\
\text { health disorders }\end{array}$ & $\begin{array}{l}\text { Parents who did not return } \\
\text { after completing the } \\
\text { intake or one session } \\
\text { beyond the intake. }\end{array}$ & $\begin{array}{l}\text { Predictors: lower level of education, parents } \\
\text { high on family/self-reliance, reliance on } \\
\text { discipline, more perceived barriers to treatment } \\
\text { at intake, expecting the child to recover } \\
\text { quickly. } \\
\text { Ethnic match with the therapist, lower levels of } \\
\text { income, acculturation, and perceptions of } \\
\text { stigma were not related to dropout. }\end{array}$ & d.o. $=29 \%$ \\
\hline $\begin{array}{l}\text { 27. De Haan } \\
\text { et al. (2014) }\end{array}$ & $\begin{array}{l}70 \\
(6-20) \\
\text { The } \\
\text { Netherlands }\end{array}$ & Not taken into account & $\begin{array}{l}\text { Birth country of } \\
\text { patient and both } \\
\text { parents: } \\
31.4 \% \text { Turkish, } 21.4 \% \\
\text { Surinamese, } 22.9 \% \\
\text { African, } 24.3 \% \text { other }\end{array}$ & $\begin{array}{l}\text { Several treatment } \\
\text { types } \\
\text { All types of mental } \\
\text { health disorders }\end{array}$ & $\begin{array}{l}\text { A patient was classified as } \\
\text { a 'dropout' when the } \\
\text { patient prematurely } \\
\text { terminated therapy but the } \\
\text { therapist did not agree on } \\
\text { this termination (i.e., } \\
\text { according to the therapist } \\
\text { the therapy should have } \\
\text { been continued). }\end{array}$ & $\begin{array}{l}\text { Predictors: a decreasing quality of the } \\
\text { therapeutic relationship during the course of } \\
\text { therapy (as judged by the child/adolescent } \\
\text { patient himself) }\end{array}$ & d.o. $=35.7 \%$ \\
\hline
\end{tabular}

Group 3: studies not reporting on different dropout percentages between ethnic groups, but analyzing whether ethnic minority background is a predictor of dropout 


\begin{tabular}{|c|c|c|c|c|c|c|c|}
\hline $\begin{array}{l}1 . \\
\text { Armbruster } \\
\& \text { Fallon } \\
(1994)\end{array}$ & $\begin{array}{l}304 \\
(0-18) \\
\text { United } \\
\text { States }\end{array}$ & $\begin{array}{l}\text { Hollingshead four- } \\
\text { factor Index of Social } \\
\text { Status } \\
41 \% \text { upper, } 19 \% \\
\text { middle, } 32 \% \text { lower, } \\
8 \% \text { uncoded }\end{array}$ & $\begin{array}{l}\text { Definition by race } \\
37 \% \text { minority }(24 \% \\
\text { African American, } 6 \% \\
\text { Hispanic, } 7 \% \text { other })\end{array}$ & $\begin{array}{l}\text { No information on } \\
\text { treatment type } \\
\text { Oppositional, } \\
\text { aggressive, antisocial } \\
\text { behavior disorders }\end{array}$ & $\begin{array}{l}\text { Failure to attend, repeated } \\
\text { cancellations resulting in } \\
\text { no further contact, or open } \\
\text { refusal of } \\
\text { recommendations for } \\
\text { further evaluation or } \\
\text { treatment. }\end{array}$ & $\begin{array}{l}\text { Predictors: one-parent family, uninsured } \\
\text { families, ethnic minority background (but not } \\
\text { after controlling for SES), lower SES, } \\
\text { combination of a nonminority parent with a } \\
\text { minority therapist }\end{array}$ & d.o. $=45 \%$ \\
\hline $\begin{array}{l}\text { 3. Kazdin et } \\
\text { al. (1994) }\end{array}$ & $\begin{array}{l}75 \\
(4-13) \\
\text { United } \\
\text { States }\end{array}$ & $\begin{array}{l}\text { Hollingshead } \\
\text { socioeconomic class } \\
26.8 \% \text { class } 5,26.8 \% \\
\text { class } 4 \text {, } \\
28.2 \% \text { class } 3,12.7 \% \\
\text { class } 2,5.6 \% \text { class } 1\end{array}$ & $\begin{array}{l}\text { Definition by race } \\
36 \% \text { minority }(32 \% \\
\text { Black, } 4 \% \text { Hispanic) }\end{array}$ & $\begin{array}{l}\text { Cognitive problem- } \\
\text { solving skills training } \\
\text { and Parent } \\
\text { management training } \\
\text { Oppositional, } \\
\text { aggressive, antisocial } \\
\text { behavior disorders }\end{array}$ & $\begin{array}{l}\text { Premature termination } \\
\text { based on the unilateral } \\
\text { decision by parent or } \\
\text { family, while inadvisable } \\
\text { and against advice of } \\
\text { clinical team. } \\
3 \text { constructed groups: } \\
\text { dropouts, matched } \\
\text { completers, unmatched } \\
\text { completers. }\end{array}$ & $\begin{array}{l}\text { Predictors: younger mother, ethnic minority } \\
\text { background, greater dysfunction, higher } \\
\text { pretreatment levels of emotional and behavioral } \\
\text { problems, lower pretreatment prosocial } \\
\text { functioning. } \\
\text { No predictors: socioeconomic status, parental } \\
\text { stress, parent psychopathology. }\end{array}$ & $\begin{array}{l}\text { No d.o. } \\
\text { percentages }\end{array}$ \\
\hline $\begin{array}{l}\text { 7. Kendall } \\
\text { \& Sugarman } \\
(1997)\end{array}$ & $\begin{array}{l}190 \\
(8-14) \\
\text { United } \\
\text { States }\end{array}$ & $\begin{array}{l}\text { Mother's level of } \\
\text { education and family } \\
\text { income } \\
\text { No information about } \\
\text { the distribution }\end{array}$ & $\begin{array}{l}\text { Definition by race } \\
80.5 \% \text { Caucasian, } \\
19.5 \% \text { ethnic minority } \\
\text { (African American, } \\
\text { Hispanic, Asian) }\end{array}$ & $\begin{array}{l}\text { Cognitive-behavioral } \\
\text { treatment } \\
\text { Anxiety disorders }\end{array}$ & $\begin{array}{l}\text { Starting treatment but } \\
\text { unilaterally decide to } \\
\text { terminate before the end } \\
\text { of the time-limited } \\
\text { treatment. } \\
\text { Refusers: were evaluated } \\
\text { and offered treatment but } \\
\text { never received it. }\end{array}$ & $\begin{array}{l}\text { Predictors: less anxiety symptoms according to } \\
\text { child reports, ethnic minority background, } \\
\text { single-parent household, experiencing that help } \\
\text { was no longer needed and that the child did not } \\
\text { like the clinic. } \\
\text { Refusers: younger than dropouts and less } \\
\text { internalizing problems than dropouts according } \\
\text { to teacher reports. }\end{array}$ & d.o. $=23 \%$ \\
\hline $\begin{array}{l}\text { 8. Baruch et } \\
\text { al. (1998) }\end{array}$ & $\begin{array}{l}134 \\
(12-24) \\
\text { United } \\
\text { Kingdom }\end{array}$ & $\begin{array}{l}\text { Jarman Index of } \\
\text { deprivation (for the } \\
\text { area of residence) } \\
71.6 \% \text { with high } \\
\text { deprivation }\end{array}$ & $\begin{array}{l}\text { Definition by race } \\
79.1 \% \text { White, } 20.9 \% \\
\text { ethnic minority }\end{array}$ & $\begin{array}{l}\text { Psychoanalytic } \\
\text { psychotherapy } \\
\text { All types of mental } \\
\text { health disorders }\end{array}$ & $\begin{array}{l}\text { Early d.o.: Dropping out } \\
\text { after the first session and } \\
\text { before the sixth session. } \\
\text { Late d.o.: Dropping out } \\
\text { after the fifth session and } \\
\text { before the } 21^{\text {st }} \text { session }\end{array}$ & $\begin{array}{l}\text { Predictors early and late d.o.: younger age, high } \\
\text { delinquency scores, high externalizing } \\
\text { problems scores, not self-referred, problems in } \\
\text { school., diagnosis of hyperkinetic or conduct } \\
\text { disorder, interpretative approach (as apposed to } \\
\text { supportive approach), non-minority status. }\end{array}$ & $\begin{array}{l}\text { Early d.o. }= \\
30,6 \% \text { Late } \\
\text { d.o. }=29,1 \%\end{array}$ \\
\hline $\begin{array}{l}\text { 9. Dierker et } \\
\text { al. }(2001)\end{array}$ & $\begin{array}{l}117 \\
(0-18) \\
\text { United } \\
\text { States }\end{array}$ & No information & $\begin{array}{l}\text { Definition by race } \\
78 \% \text { Caucasian, } 22 \% \\
\text { ethnic minority }\end{array}$ & $\begin{array}{l}\text { No information on } \\
\text { treatment type } \\
\text { All types of mental } \\
\text { health disorders }\end{array}$ & $\begin{array}{l}\text { Went through the (SRT) } \\
\text { service review team } \\
\text { process, but excited } \\
\text { before goals were met } \\
\text { and/or before the child }\end{array}$ & $\begin{array}{l}\text { Predictors d.o.: depressed and isolated } \\
\text { behaviors, substance abuse problems, multiple } \\
\text { referral reasons. } \\
\text { Predictors refusal: considered less urgent at the } \\
\text { time of referral, multiple referral reasons. }\end{array}$ & $\begin{array}{l}\text { d.o. }=20.5 \% \\
\text { Refusal }= \\
46,2 \%\end{array}$ \\
\hline
\end{tabular}




$\begin{array}{ll}\text { 10. Garcia } & 344 \\ \text { \& Weisz } & (7-18) \\ (2002) & \text { United } \\ & \text { States }\end{array}$

9-point Hollingshead occupation score

The occupation mean

was 3.47 (higher

scores $=$ higher SES)
No information on treatment type All types of mental health disorders treatment disorders

No information on treatment type

A reported history of maltreatment

United

States

1711

Halliday- (6-18)

$\begin{array}{ll}\text { Boykins et } & \text { United } \\ \text { al. (2005) } & \text { States }\end{array}$

17. Shelef et 91

al. (2005) (12-18)

United

States

No information on

distribution

Parent education and family income

$25.1 \%$ no high school,

$38.5 \%$ completed high

school, 36.4\% college

$49.3 \%$ annual income

$<20000$

Poverty index of

Hollingshead and

Redlich

$20 \%$ very poor, $19 \%$
American, $4.3 \%$ other

Definition by race

45.5\% White, $16.6 \%$

12.2\% Hispanic, 1.7\%

Asian Pacific Islander,

$23.9 \%$ other/mixed

Definition by race

64.4\% Caucasian,

8.8\% African

American, 6.5\%

Asian, 5.1\% Latino,

$5.1 \%$ other/mixed

Definition by race

47\% White, 47\%

other
African American, 6\%

Multisystemic

therapy 51\% Caucasian, 16\% African American,

14\% Latino, 19\% other
Definition by race

was linked to external services.

Refusers: were never

served by the system.

Clinic record information:

statements that

termination was 'against

therapist advice' or

'premature' were used to

indicate dropout.

Early d.o.: five treatment

sessions or less.

Late d.o.: six sessions or

more.

Beginning to attend

treatment sessions but

unilaterally terminate the

treatment program.

Discontinuing without the consent of the therapist.

median number of

sessions (eight).

Reasons for discharge reported by therapists

(i.e., successful vs. not

health disorders $\quad$ successful) eight sessions
Exposure-based

Phobic and anxiety

No differences in terms of ethnicity

Completing less than
Predictors: a perceived lack of therapist involvement and investment in the child and parent, a belief that the therapist was not competent or effective, and a perception that going to the clinic was not going to help the child and was too costly anyway. No

significant differences were found between both dropout groups.

No predictors: socioeconomic status, ethnic background

Predictors: null findings emerged in exploring for differences between Hispanic/Latino and

Euro-American completers and noncompleters.

Predictors: maltreated child accompanied to treatment by a maltreating parent and to e lesser extend by a non-perpetrator parent. No predictors: socioeconomic status, ethnic background, parent psychopathology, life events be discharged for successful reasons than

Caucasian families. For the other ethnic groups no differences were found. Ethnic match between caregiver and therapist was positively associated with discharge success.

Predictors: Parent-therapist alliance

d.o. $=18.7 \%$

d.o. $=61,6 \%$

d.o. $=22,6 \%$

No d.o percentages

d.o. $=33 \%$

No predictors: Adolescent-therapist alliance, ethnic background 
poor, $39 \%$ working

class, $12 \%$ upper-

middle class, $9 \%$

upper class

18. Stevens 186

et al. (2006) (5-17)

United

States

20. Miller et 447

al. (2008) (2-17)

United

States
Definition by race

67.9\% Caucasian,

$28.3 \%$ African

American, $0.5 \%$

Hispanic, $3.3 \%$

other/mixed

Definition by race

71.2\% White, $28.8 \%$

African American

All types of mental
health disorders

No information on

treatment type

All types of mental

health disorders

No information on

treatment type

health disorders

\section{2}

al. (2011) United

States
Gonzales et (5-18)
Medicaid health

coverage was the

indicator for low-to

middle-class range of

SES

$55 \%$ received

Medicaid coverage

Family income

US Census poverty

level

$\begin{array}{ll}\text { Medicaid health } & \begin{array}{l}\text { Definition by race } \\ \text { coverage was the }\end{array} \\ \text { indicator for low-to } & 24.4 \% \text { Caucasian, } \\ \text { middle-class range of } & \text { American, } 15.7 \% \\ \text { SES } & \text { Hispanic/Latino, } \\ \text { 67\% received } & 10.1 \% \text { other } \\ \text { Medicaid coverage } & \end{array}$

No information on treatment type anxiety disorders
Therapist indication that treatment goals had not been at least partially met.

1) Intake retention: Those who attended only one (intake) appointment. 2) Mutual termination: terminating without therapist agreement. 3) Mean treatment duration: comparing number of sessions of individual with mean number of total sample Clinically significant youths/families who unilaterally decided to terminate and treatment and a lower quality of the therapistdiscontinued contact with clinic (terminations for reasons beyond ones control were seen as nond.o.)

Phase of treatment d.o. (PT): pre-treatment (0-1 sessions), early (2-6 sessions), late (>6 sessions) family relationship.

No predictors: ethnic background,

socioeconomic status

No d.o.

percentages,

only cases

indicated as

dropout

were

included d.o. 1) = $17 \%$

lower income, Axis-I adjust disorder, no Axis-IV stressors

No predictors d.o. 1 and 2: ethnic background Predictor shorter treatment duration: African American background

d.o. 2) $=$ $38.6 \%$ d.o. 3$)=$

$66.2 \%$

attended

fewer

sessions

\section{predictors CR: high level of depression}

symptoms

predictors PT: minority status predicted pre-

treatment d.o. (only African Americans had

higher pre-treatment d.o. rates, not the other minorities)

d.o. $\mathrm{CR}=$

51,3\%,

d.o. PT:

pre-

treatment $=$

$12,7 \%$

early $=$

$14,2 \%$

late $=24,4 \%$ 


$\begin{array}{lll}\text { 23. Warnick } & 1098 & \text { Medicaid health } \\ \text { et al. (2012) } & (5-18) & \text { coverage was the } \\ & \text { United } & \text { indicator for low-to } \\ & \text { States } & \text { middle-class range of } \\ & & \text { SES } \\ & & 90.3 \% \text { received } \\ & & \text { Medicaid coverage }\end{array}$

$\begin{array}{lll}\text { 24. Stein et } & 2077 & \text { Only Medicaid- } \\ \text { al. (2012) } & (6-12) & \begin{array}{l}\text { enrolled children were } \\ \text { included }\end{array}\end{array}$

States

$\begin{array}{ll}\text { 25. Bagner } & 44 \\ \text { et al. (2013) } & (1-6) \\ & \begin{array}{l}\text { United } \\ \text { States }\end{array} \\ & \\ & \\ & \\ 26 . & 73 \\ \text { Schneider et } & (4-12) \\ \text { al. (2013) } & \text { United } \\ & \text { States }\end{array}$

Medicaid coverage
Definition by race

$43.2 \%$ Caucasian,

$28.2 \%$ African

American, 23.1\%

Hispanic, $5.5 \%$ other
Definition by race

(obtained from state

files): $48 \%$ Caucasian,

$32 \%$ African

American, 20\% other.

\section{Poverty (meeting \\ federal guidelines) and $72.7 \%$ Caucasian, \\ maternal education $\quad 27.3 \%$ Black/ \\ (completed high Hispanic/Biracial}

school or less): $34.1 \%$

was

socioeconomically

disadvantaged

No information

Self-identification:

$43.8 \%$ White, $56.2 \%$

ethnic minority
No information on

treatment type

All types of mental

health disorders
Individual, family, and group outpatient

therapies, intensive community-based services

Attention-Deficit

Hyperactivity

Disorder

Parent-Child

Interaction Therapy

Externalizing

behavior problems and developmental delay or borderline developmental delay

Parent training and

school-based

behavioral

interventions
Three definitions

1. Clinician judgment:

youths were classified as

dropouts based on the

clinician coded reason for

discharge

2. Missed last

appointment: youths were

classified as dropouts if

they did not attend their

last scheduled

appointment

3. Dose: youths were

classified as dropouts if

they attended less than 12 sessions within 4 months

A treatment was

considered prematurely

terminated if there was a

90 -day gap in care.

Not finishing all planned therapy sessions

Prior to the initiation of therapy: discontinuing services at any point after completion of the initial predictors def 1: African-American ethnicity,

single caregiver household

predictors def 2: African American ethnicity,

Hispanic ethnicity, single caregiver household,

having Medicaid insurance

predictors def 3: Hispanic ethnicity, living with

non-biological family, longer wait time d.o. with def

$1=63,1 \%$

d.o. with def

$2=56,6 \%$

d.o. with def

$3=88,1 \%$ alone (in contract to receiving medication as well), African American ethnicity, living in an urban community (in contrast to living in a rural area)

d.o. $=38 \%$ (within 6 months after treatment started)

Predictors: minority status, single-parent household, having higher cumulative risk (i.e., more risk factors: minority status, singleparent, socioeconomic disadvantage, lower maternal intelligence, maternal distress) No predictor: socioeconomic status

Predictors d.o. prior to treatment: ethnic minority status, severity of

hyperactive/impulsive and CD symptoms, single-parent household, not receiving ADHD d.o. prior to treatment $=$ $22 \%$ d.o. during 
Attention-Deficit

Hyperactivity

Disorder
Group 4: Studies reporting on other ethnicity-related variables

\begin{tabular}{lll}
\hline 4. Yeh et al. & 4616 & Medi-Cal status \\
(1994) & (6-17) & (patients qualifying for \\
& United & Medi-Cal considered \\
& States & as being in poverty)
\end{tabular}

States

16

et all. (2005) United

States
19. Robbins
30
et al. (2006) (12-18)
United
States

as being in poverty)

-identification

$26.4 \%$ African-

American, 19.6\%

Asian-American,

$21.6 \%$ Caucasian-

American, 32.5\%

Mexican-American

No information on
treatment type
All types of mental
health disorders
(disorders that feature
psychotic symptom
and often require
medication were
defined as serious)
Motivational
enhancement therapy,
Individual behavioral
therapy,
Multidimensional
family therapy
Substance abuse
disorders
Multidimensional
family therapy
Drug abusers

Definition by race

$80 \%$ African

American, 16.7\%

level at or

poverty

Definition by race

61\% Caucasian, $32 \%$

African American, 7\%

Latino

White, 3.3\% Hispanic
Clients not returning to

the mental health facility

after the first session.

Length of treatment (total

number of sessions) was

taken into account.

Attending less tan two-

thirds of the indented

Completing less than

eight sessions and being

classified by the therapist as a dropout medication

eatment $=$

CD symptoms, single-parent household

No predictor: socioeconomic status

$39 \%$ assessment packet but

prior to the first treatmen

session.

During treatment: signing

the treatment contract and

completing at least one

treatment session, but

discontinuing treatment

prior to completing the

last planned session.
Predictors of d.o. during treatment: severity of

Predictors for adolescents: more serious

admission diagnosis, no ethnic match with

No d.o.

therapist (accounted for African Americans,

Mexican-Americans and Asian-American, not

for Caucasian-Americans),

Predictors for children: none, no effect of

ethnic match
Predictors: no ethnic match between therapist and patient (especially a Caucasian therapist with a minority patient), no gender match between therapist and patient (especially

female therapist with male patient)

d.o. ethnic match $(\mathrm{N}=$ 379) $=21 \%$ d.o. no

ethnic match $(\mathrm{N}=163)=$ $45 \%$

Predictors: being older, fewer internalizing and externalizing problems as judged by the

No d.o. percentages judged by the parents, reduction in both parenttherapist and adolescent-therapist alliance from session one to session two for African American families 

Table 2: Summary of the main findings concerning dropout percentages and dropout predictors in various ethnic groups

\begin{tabular}{|c|c|c|}
\hline Predictor & Study number & Conclusion \\
\hline $\begin{array}{l}\text { African American } \\
\text { background }\end{array}$ & $2,22,23,24$ & $\begin{array}{l}\text { Higher dropout rates compared to Caucasian and other } \\
\text { ethnic minority patients }\end{array}$ \\
\hline $\begin{array}{l}\text { Hispanic or Mexican } \\
\text { American background }\end{array}$ & $11,21,22,23$ & Similar dropout rates compared to Caucasian patients \\
\hline $\begin{array}{l}\text { Asian American } \\
\text { background }\end{array}$ & $2,7,14,15$ & $\begin{array}{l}\text { Lower or similar dropout rates compared to Caucasian } \\
\text { patients }\end{array}$ \\
\hline $\begin{array}{l}\text { Ethnic minority } \\
\text { background general (US) }\end{array}$ & $9,10,13,14,17,18$ & $\begin{array}{l}\text { Ethnic minority status was not a predictor of higher } \\
\text { dropout percentages }\end{array}$ \\
\hline Asian background (UK) & 12 & $\begin{array}{l}\text { Higher dropout rates compared to ethnic majority English } \\
\text { patients }\end{array}$ \\
\hline $\begin{array}{l}\text { Ethnic minority } \\
\text { background general (The } \\
\text { Netherlands) }\end{array}$ & 27 & $\begin{array}{l}\text { Similar dropout rates for ethnic minority youth compared } \\
\text { majority Dutch youth }\end{array}$ \\
\hline Younger mother & 5 & $\begin{array}{l}\text { Was found to be a predictor in Caucasian but not in African } \\
\text { American families }\end{array}$ \\
\hline Single-parent family & 5 & $\begin{array}{l}\text { Was found to be a predictor in Caucasian but not in African } \\
\text { American families }\end{array}$ \\
\hline Parental psychopathology & 5 & $\begin{array}{l}\text { Was found to be a predictor in Caucasian but not in African } \\
\text { American families }\end{array}$ \\
\hline Overall child dysfunction & 5 & $\begin{array}{l}\text { Was found to be a predictor in Caucasian but not in African } \\
\text { American families }\end{array}$ \\
\hline $\begin{array}{l}\text { An unbalanced } \\
\text { therapeutic alliance (i.e., } \\
\text { parent-therapist alliance } \\
\text { minus adolescent- } \\
\text { therapist alliance) }\end{array}$ & 21 & $\begin{array}{l}\text { Was found to be a predictor for Hispanic but not for } \\
\text { Caucasian families }\end{array}$ \\
\hline $\begin{array}{l}\text { Decreasing quality of the } \\
\text { therapeutic alliance }\end{array}$ & 27 & $\begin{array}{l}\text { Was found to be a predictor for both ethnic minority as } \\
\text { ethnic majority patients }\end{array}$ \\
\hline $\begin{array}{l}\text { Low socioeconomic } \\
\text { status }\end{array}$ & $\begin{array}{l}1,2,3,5,6,10,11,14 \\
21,23,25,26\end{array}$ & $\begin{array}{l}\text { In most studies it was no predictor for dropout, especially } \\
\text { not with African American patients }\end{array}$ \\
\hline $\begin{array}{l}\text { Ethnic match between } \\
\text { therapist and } \\
\text { parent/patient }\end{array}$ & $1,4,11,15,16,21$ & $\begin{array}{l}\text { It could reduce the chance to drop out, especially prevent } \\
\text { the combination of a Caucasian patient and a non-minority } \\
\text { therapist. For adolescents, an ethnic match was more } \\
\text { important than for children. }\end{array}$ \\
\hline
\end{tabular}


Figure 1: Flow diagram of the literature search

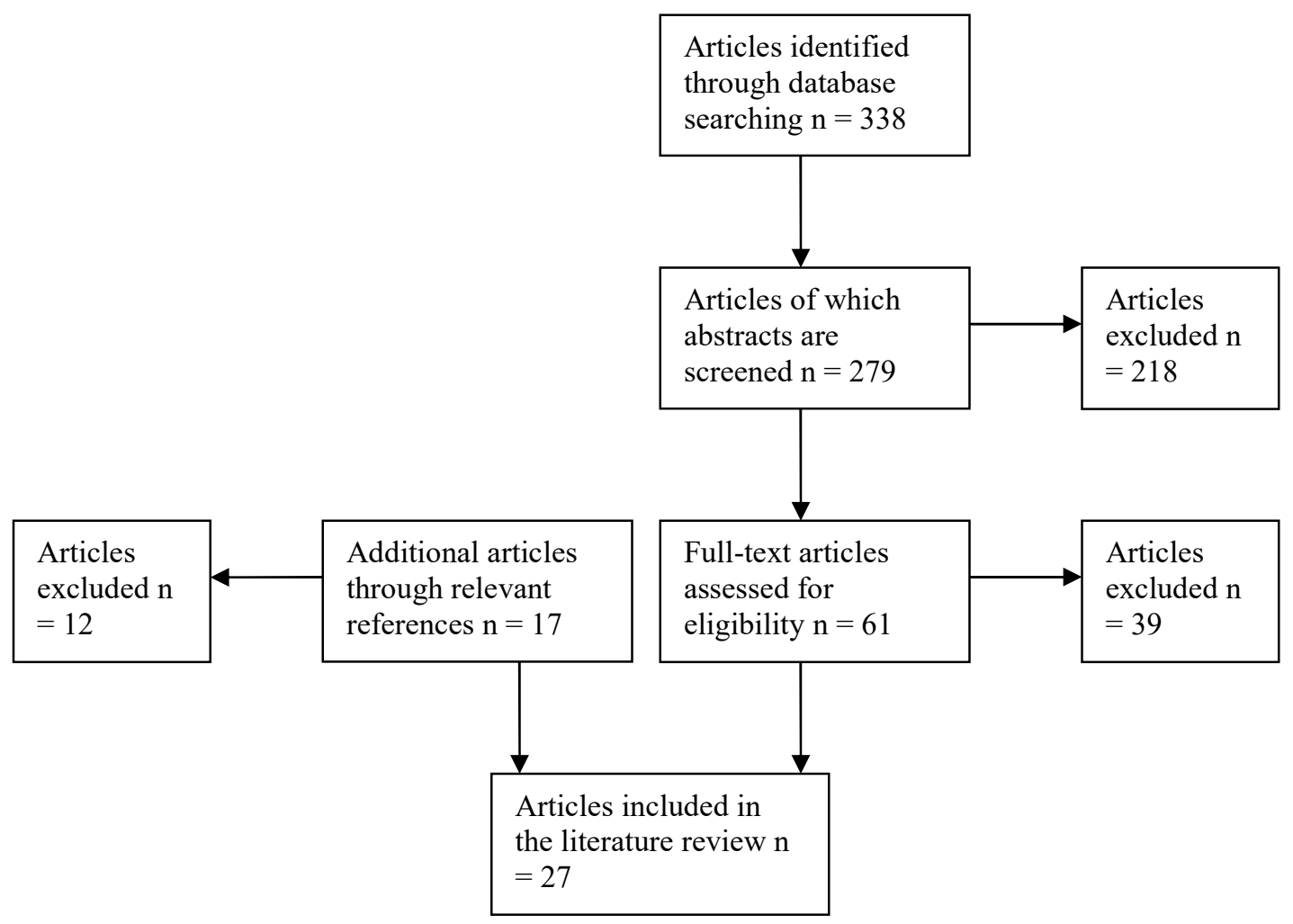

